\title{
A COMPARATIVE STUDY OF FIVE ANALGESICS*
}

\author{
A. F. Pasquet, M.D., C.M., D.A.(McGill), $\dagger$ F. MacDonald, B.A., $\ddagger$ \\ AND WM. JAMES, B.A. $\$$
}

NeWER AND BETTER ANALGESICS are constantly being produced with the result that the selection of an analgesic for a specific purpose is often based on personal feelings towards the manufacturer's agent rather than on the actual value of the drug.

We wondered whether any one analgesic was superior to the others in anaesthesia, using the technique of thiopentone, $\mathrm{N}_{2} \mathrm{O}$, and $\mathrm{O}_{2}$ plus intravenous analgesics and relaxants. We had used the following five drugs extensively: meperidine thydrochloride (Demerol ${ }^{\circledR}$ ), anileridine (Leritine ${ }^{\circledR}$ ), oxymorphan (Numorphan $\left.{ }^{\circledR}\right)$, dipipanone hydrochloride '(Pipadone $\left.{ }^{\circledR}\right)$, and Ciba 20684-BA, claiming various advantages for each. However, since such clinical impressions are quite meaningless, it was decided to carry out a small blind study to compare the five drugs.

\section{METHODS}

Study of the standard techniques for comparing drugs by using varying amounts of each drug to produce a standard response ${ }^{1-4}$ suggested that such methods would not produce information of value from the small series proposed. It is realized that analgesics produced by reputable manufacturers do possess reliable analgesic activity and that, with proper dosage, optimum operative conditions can be produced by all. The most suitable drug or drugs for our technique, therefore, will be determined by the nature and severity of the operative and postoperative side-effects elicited by the optimum dosage. The following procedure was therefore adopted:

1. The drugs were standardized according to our previous experience and according to the potency ratio claimed by the manufacturers. 1

2. The drugs were administered in fixed amounts according to the weight of the patient, in dosage which, according to our experience, produced optimum operative conditions.

3. The surgical technique was standardized.

4. Our observations were meticulously recorded both during surgery and during the postoperative period.

5. The results were compared by means of the $\chi^{2}$ test of medians.

*From the Department of Anaesthesia, Dalhousie University, and the Victoria General Hospital, Halifax, Nova Scotia.

†Associate Professor of Anaesthesia.

†Medical Student and Summer Research Fellow, Faculty of Medicine.

$\S$ Research Fellow in Psychology, Faculty of Medicine.

TThe potency ratio of the manufacturers was adhered to except in the case of Numorphan and Ciba 20684-BA where, from our previous experience, it was found that much smaller doses could be used to produce the same operative conditions. 
This is a rather unorthodox method, but one which provides more reliable information from a small series.

The surgical techniques were: (1) vaginal hysterectomy; (2) vaginal hysterectomy and repair; (3) perineal repair. These provided us with a relatively standard procedure in which surgical reflexes are quite severe and variations in time of operation and in age of patient are moderate and within a definite range. These variations are shown in Table I.

TABLE I

\begin{tabular}{|c|c|c|c|c|c|}
\hline & \multicolumn{5}{|c|}{ Drug } \\
\hline & A & B & $\mathrm{C}$ & $\mathrm{D}$ & $E$ \\
\hline $\begin{array}{l}\text { Type of operation } \\
\text { Vaginal hysterectomy } \\
\text { Vaginal hyst. and repair } \\
\text { Perineal repair }\end{array}$ & $\begin{array}{l}6 \\
6 \\
2\end{array}$ & $\begin{array}{l}6 \\
8 \\
2\end{array}$ & $\begin{array}{l}8 \\
5 \\
1\end{array}$ & $\begin{array}{l}6 \\
6\end{array}$ & $\begin{array}{l}9 \\
2\end{array}$ \\
\hline $\begin{array}{l}\text { Duration of operation (in } 1 \\
\text { Average } \\
\text { Range }\end{array}$ & $\begin{array}{l}\text { utes) } \\
52 \\
20-100\end{array}$ & $\begin{array}{l}55 \\
25-125\end{array}$ & $\begin{array}{l}50 \\
30-85\end{array}$ & $\begin{array}{l}57 \\
35-95\end{array}$ & $\begin{array}{l}45 \\
25-65\end{array}$ \\
\hline $\begin{array}{l}\text { Age of patients } \\
\text { Average } \\
\text { Range }\end{array}$ & $\begin{array}{l}+3 \\
29-59\end{array}$ & $\begin{array}{l}41 \\
31-58\end{array}$ & $\begin{array}{l}44.5 \\
34-62\end{array}$ & $\begin{array}{l}405 \\
28-54\end{array}$ & $\begin{array}{l}40 \\
31-50\end{array}$ \\
\hline
\end{tabular}

To avoid any possibility of bias, the cases were divided into the five groups (A, B, C, D, and E) only after all data had been collected. The identity of each group remained unknown until all analyses had been completed. At this time A was found to be meperidine; $\mathrm{B}$, Ciba 20684-BA; C, anileridine; D, oxymorphan; and $\mathrm{E}$, dipipanone hydrochloride.

All drugs were diluted so that each cubic centimetre was of equal analgesic potency (equivalent to $10 \mathrm{mg}$. of meperidine) based on the manufacturers' information and on our own previous experiences (see Table II). If these dilutions

TABLE II

Equivalent Analgesic Dosage OF THE First Five DRUgS UsED

\begin{tabular}{lrr}
\hline Meperidine & 100 & $\mathrm{mg}$. \\
Anileridine & 40 & $\mathrm{mg}$. \\
Oxymorphon & 1 & $\mathrm{mg}$. \\
Dipipanone $\mathrm{HCl}$ & 25 & $\mathrm{mg}$. \\
Ciba 20684-BA & $0.02 \mathrm{mg}$. \\
\hline
\end{tabular}

were estimated correctly the degree of surgical analgesia or the operative conditions produced by all the drugs should be about the same. The equipotency of the drugs used was tested by carefully recording all the patients' responses to surgical stimulation. This was carried out by grading the actual responses from 0 to 3 for: (1) arm movement; (2) leg movement; (3) facial movement; (4) withdrawal of body; (5) straining; (6) hyperventilation; (7) breath-holding; (8) laryngeal spasm. The sum of these in each patient was used for statistical comparison, by the method to be described. 
An analysis of the results shown in Table III indicates no significant difference in potency between the drugs.

, TABLE III

Response to Surgical Stimuli

\begin{tabular}{|c|c|c|c|c|c|c|}
\hline & \multicolumn{5}{|c|}{ Drug } & \multirow[b]{2}{*}{ Total } \\
\hline & A & B & $\mathrm{C}$ & $\mathrm{D}$ & $\mathrm{E}$ & \\
\hline $\begin{array}{l}\text { Satisfactory } \\
\text { Unsatisfactory }\end{array}$ & 4 & 10 & 9 & $\begin{array}{l}7 \\
5\end{array}$ & 4 & 34 \\
\hline Total & 14 & 16 & 14 & 12 & 11 & \\
\hline
\end{tabular}

The drug dilutions were prepared by adding the correct amount of analgesic (Table II) to distilled water and preservative in 30 -c.c. vials. Two vials (60 c.c.) of each drug were prepared. Each drug (in dilution) was then given a number 1 to 5 and this number was recorded by someone not associated with the study. The drugs were used at random until the supply was nearly exhaưsted. (If the quantity of drug left in a set of two vials was judged to be insufficient for a complete case, it was discarded.)

Another set of vials of drugs (two vials of each drug or 60 c.c.) was then prepared and numbered 6 to 10 . The anaesthetist had no knowledge of the relationship of the drugs from one set to another.

In this manner five sets of vials of the drugs were used (numbered 1 to 5 , 6 to 10,11 to 15,16 to 20 , and 21 to 25 ) for a total of 67 cases.

\section{Method of Administration and Observation}

Patients were seen the day before surgery and data recorded. At this time the dosage of the various drugs and agents to be used during surgery was calculated and recorded. Administration of the drugs and agents was carried out according to the schedule in Table IV.

Atropine only was given as premedication, three-quarters of an hour before surgery. This rigid standardization was used to eliminate, as far as possible, all variables of administration and dosage. It was arrived at after long clinical trial of these agents in similar operations with this particular anaesthesia technique.

The dosage of analgesics may be considered heavy, but proved satisfactory. Nevertheless, it is not recommended as a routine procedure in all types of/surgery or in all types of patients.

Detailed operative records were kept showing the quantity and the time of administration of all drugs. All patients' responses were recorded as they occurred, as well as the time and duration of controlled and assisted respiration. Pulse and respiratory rates were recorded every five minutes or oftener when changes occurred rapidly. The blood pressure was recorded by means of a "Continuous Systolic Monitor." The respiratory minute volume was measured by a "Minute Volume Meter (Ohio)." Postoperative apnoea and amount of Lorfan used were also recorded.

Postoperative records were kept on the charts shown in Figure 1 (Recovery 


\section{Method of AdMinistration}

\begin{tabular}{|c|c|}
\hline $\begin{array}{l}\text { Analgesics (diluted) } \\
\text { 1. Initial dose a) } \\
\text { (equivale } \\
\text { 2. Dose after an } \\
\text { (equivale } \\
\text { 3. Subsequent a } \\
\text { (equivale } \\
\text { Administ }\end{array}$ & $\begin{array}{l}\text { prior to surgery } \\
\text { eridine } / 100 \mathrm{lb} .)=2.5 \text { c.c. } / 100 \mathrm{lb} . \text { of body wt. } \\
\text { eridine } / 100 \mathrm{lb} .)=1 \text { c.c. } / 100 \mathrm{lb} . \text { of body wt. } \\
1 \text { st dose }-5 \text { min. after No. } 2 \\
\text { 2nd dose }-8 \text { min. later } \\
\text { 3rd dose }-10 \text { min. later } \\
\text { 4th dose }-15 \text { min. later } \\
5 \text { th dose }-20 \text { min. later }\end{array}$ \\
\hline $\begin{array}{l}\text { Thiopentone } \\
\text { Induction } \\
\text { Maintenance }\end{array}$ & $\begin{array}{l}250 \mathrm{mg} . / 100 \mathrm{lb} .(2.5 \mathrm{mg} \cdot / \mathrm{lb} .) \\
25 \mathrm{mg} \cdot / 100 \mathrm{lb} .(0.25 \mathrm{mg} \cdot / \mathrm{lb} .) \\
\text { as required (hardly any required) }\end{array}$ \\
\hline $\begin{array}{l}\text { Succinylcholine } \mathrm{Cl} \\
\text { Intubation dose } \\
\text { Subsequent dose }\end{array}$ & $\begin{array}{l}40 \mathrm{mg} . / 100 \mid \mathrm{lb} .(0.4 \mathrm{mg} . / \mathrm{lb} .) \\
20 \mathrm{mg} . / 100 \mid \mathrm{lb} ., \text { as required }\end{array}$ \\
\hline $\begin{array}{l}\mathrm{N}_{2} \mathrm{O} \text { and } \mathrm{O}_{2} \\
\text { Administered in } \mathrm{s} \\
\quad \text { assisted or } \mathrm{cc}\end{array}$ & $\begin{array}{l}\text { Flow set at } 6 \text { litres/min. of } \mathrm{N}_{2} \mathrm{O} \\
2 \text { litres/min. of } \mathrm{O}_{2} \\
\text { h Emerson minute-volume meter in circuit. Respiration } \\
\text { hinute-volume was less than } 4 \text { litres/min. (not accurate) }\end{array}$ \\
\hline
\end{tabular}

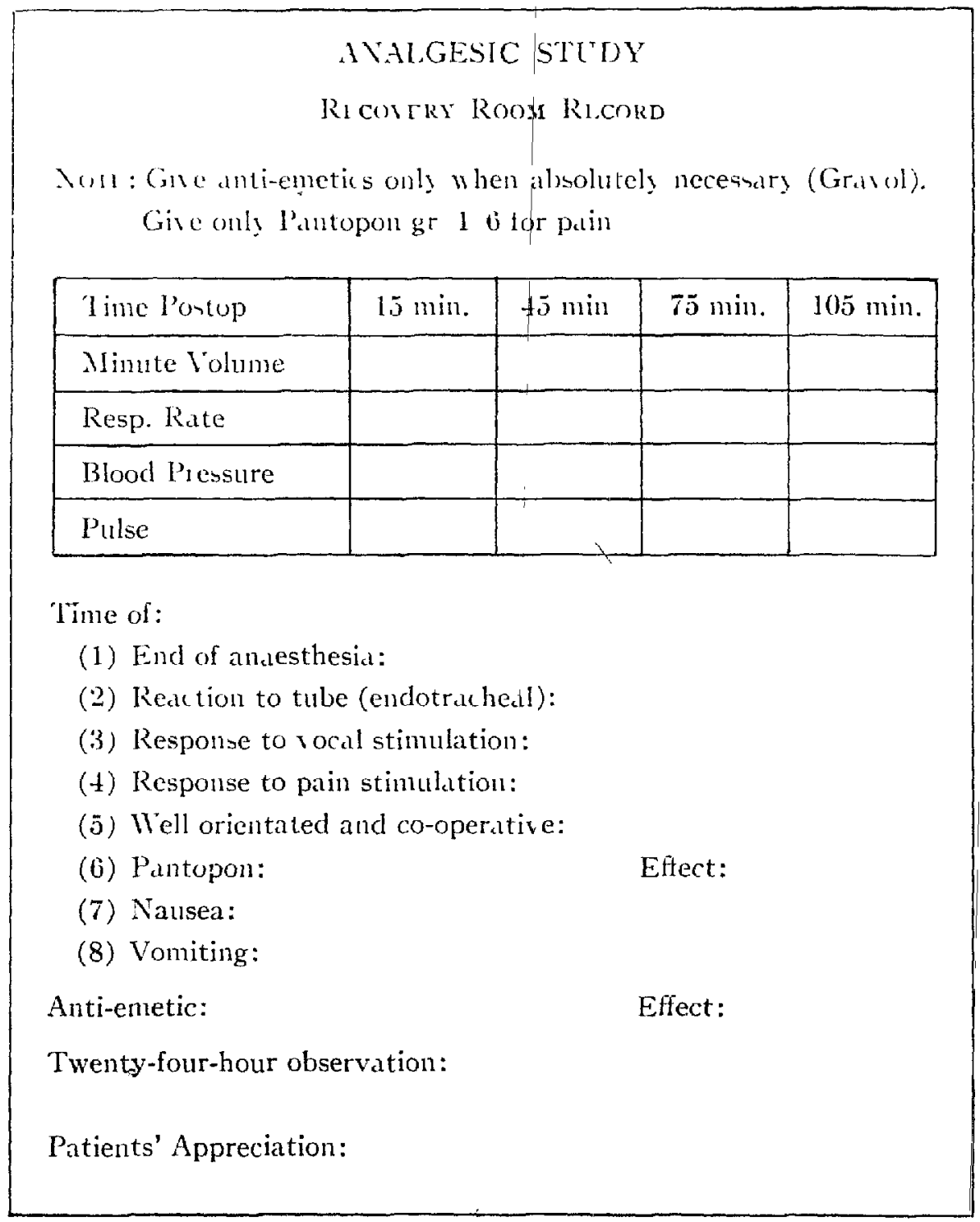




\begin{tabular}{|c|c|c|c|}
\hline \multicolumn{4}{|c|}{ A $A L G E S I C$ STUDY } \\
\hline \multicolumn{2}{|c|}{$\begin{array}{l}\text { Rating: } \\
0-N 11 \\
\text { 1-Noderate } \\
\text { 2-Severe } \\
\text { 3-Very Severe }\end{array}$} & $\begin{array}{l}\text { Patient: } \\
\text { Drug No.: }\end{array}$ & \\
\hline \multicolumn{4}{|c|}{ 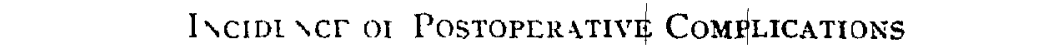 } \\
\hline & $\begin{array}{l}\text { Inmmediately } \\
\text { Postop. }\end{array}$ & $\begin{array}{l}\text { In Recovery } \\
\text { Roonl }\end{array}$ & Next 24 hours \\
\hline Nausea & 5 & & \\
\hline \multicolumn{4}{|l|}{ Vomiting } \\
\hline \multicolumn{4}{|l|}{ Drow siness } \\
\hline \multicolumn{4}{|l|}{ Restlessness } \\
\hline \multicolumn{4}{|l|}{ Headache } \\
\hline \multicolumn{4}{|l|}{ Vertigo } \\
\hline \multicolumn{4}{|l|}{ Hypotension } \\
\hline \multicolumn{4}{|c|}{$\begin{array}{l}\text { Answering questions: } \\
\text { and } \\
\text { Obeying questions. }\end{array}$} \\
\hline \multicolumn{4}{|l|}{ Total: } \\
\hline \multicolumn{4}{|c|}{ Time in Recovery Room: } \\
\hline $\begin{array}{r}\text { Pain: Subjective } \\
\text { \& Objective }\end{array}$ & & & \\
\hline
\end{tabular}

FIGURE 2

Room Record) and Figure 2, which is a summary and analysis of the postoperative period for 24 hours. At the conclusion of the study, all the recorded data were classified and charted on a master chart.

Each criterion was scored and the results analysed statistically by one of us by means of the $\chi^{2}$ test of medians. This test may be used whenever a variable may be ranked. In the present case, the null hypothesis against which the observed data were tested is that, for each drug, the difference in the proportion of observations lying above and those lying below the over-all median value is not statistically significant. (If the drug does not affect the outcome, roughly equal numbers would be expected to be above and below the median value.) This test does not require the criteria to meet absolute standards; instead, it allows the separation of the cases into two equal groups: those considered more satisfactory and those less satisfactory (referred to as unsatisfactory) for statistical analysis and comparison.

\section{RESUlTs}

The data indicated in the following sections were analysed and compared. 


\section{A. During Surgery}

\section{Cardiovascular Changes (Tables V and VI)}

(a) It had been our impression that there was nearly always a rise in blood pressure following the initial dose of analgesic. When the results were analysed, this was found to be incorrect. In only 25 cases was there a rise in blood pressure, while 7 actually had a small drop, and 35 showed no change at all. For purpose of analysis it was decided that those showing no change would be termed satisfactory (Table V). It was found that there was no significant difference among the drugs used.

TABLE $V$

Following Initial Dose of Analgesic

\begin{tabular}{lrrrrrrr}
\hline & \multicolumn{7}{c}{ Drug } \\
\cline { 2 - 6 } & A & B & C & D & E & Total \\
\hline Rise in B.P. 0-70 mm. Hg & 6 & 7 & 3 & 4 & 5 & 25 \\
Drop in B.P. 0-20 mm. Hg & 1 & 1 & 2 & 0 & 3 & 7 \\
Total, unsatisfactory & 7 & 8 & 5 & 4 & 8 & 32 \\
No change in B.P , satisfactory & 7 & 8 & 9 & 8 & 3 & 35 \\
Total & 14 & 16 & 14 & 12 & 11 & \\
\hline
\end{tabular}

(b) Our impression had been that there was nearly always a severe drop in blood pressure following the induction dose of thiopentone. This proved to be quite correct. Six cases showed a slight rise in blood pressure, while all others, were lowered in varying degrees. For the purpose of analysis it was decided that a small rise in blood pressure or a moderate drop $(30 \mathrm{~mm}$. $\mathrm{Hg}$ or less) would be considered satisfactory (Table VI). Again there was no statistical difference among the drugs used.

TABLE VI

FOLlOWING THIOPENTONE INDUCTION

\begin{tabular}{lrrrrrrr}
\hline & \multicolumn{7}{c}{ Drug } \\
\cline { 2 - 6 } & A & B & C & D & E & Total \\
\hline Rise in B.P. 0-60 mm. Hg & 2 & 2 & 1 & 0 & 1 & 6 \\
$\begin{array}{l}\text { Drop in B.P. 0-30 mm. Hg } \\
\text { Total, satisfactory }\end{array}$ & 5 & 9 & 5 & 7 & 2 & 28 \\
$\begin{array}{l}\text { Drop in B.P. 30-100 mm. Hg, } \\
\quad \text { unsatisfactory }\end{array}$ & 7 & 11 & 6 & 7 & 3 & 34 \\
Total & 14 & 16 & 8 & 5 & 8 & 33 \\
\hline
\end{tabular}

\section{Respiratory Depression during Surgery}

This proved to be rather difficult to measure as relaxants were used to control the patients' responses to stimulation. However, on reviewing the charted data, certain facts stood out: $(a)$ There was no significant difference in the total amount of relaxânt used with each drug. (b) As controlled or assisted respiration was instituted whenever the minute volume was 4 litres per minute or less, it was evident that when certain drugs were used much longer periods of controlled, respiration were required than for others. 
It was assumed, therefore, that this difference in duration of controlled respiration was a function of the depressant effect of the drugs used, regardless of how it was brought about. The duration of controlled respiration as well as thea duration of spontaneous respiration was totalled for each case and the ratio of the duration of spontaneous respiration to the duration of controlled respitation was used as a criterion of the respiratory depressant effect of each drug for statistical comparison. As shown in Table VII there were marked differences with drugs $B$ and $D$, these having less depressant effect than the others.

TABLE VII

Respiratory Depression during Surgery

(Ratio of spontaneous to controlled respiration)

\begin{tabular}{lrrrrrrr}
\hline & \multicolumn{7}{c}{ Drug and rating } \\
\cline { 2 - 6 } & $\mathrm{A}, 3$ & $\mathrm{~B}, 1$ & $\mathrm{C}, 5$ & $\mathrm{D}, 2$ & $\mathrm{E}, 4$ & Total \\
\hline Satisfactory & 7 & 12 & 3 & 8 & 4 & 34 \\
Lnsatisfactory & 7 & 4 & 11 & 4 & 7 & 33 \\
Total & 14 & 16 & 14 & 12 & 11 & \\
\hline
\end{tabular}

Conclusions: (1) The drugs differ in their effects on respiration. This is probable at the 5 per cent level (i.e. the odds are more than 20:1 that they exert a differential effect).

(2) 'In particular, B is a better drug than C. This is probable at the 2 per cent level (i.e. the odds are more than 50:1 that there is a difference between drugs $B$ and $C$ ).

(3) And D is a better drug than $C$. This is probable at the 5 per cent level.

\section{B. During the Postoperative Period}

\section{Orientation and Co-operation}

It was assumed that the patient leaving the operating room should be as well orientated and as co-operative as possible. To measure this, we recorded the tine from cessation of anaesthesia until the patient $(a)$ answered questions intelligently, and $(b)$ obeyed commands willingly. The sum of $(a)$ and $(b)$ was used as a criterion, the lower values being considered the more satisfactory (Table VIII). Again there were significant differences, with drugs B and D being superior to the others.

TABLE VIII ,

Orientation and Co-operation (postoperative)

(Time from end of anaesthesia to answering questions and obeying commands)

\begin{tabular}{lrrrrrrr}
\hline & \multicolumn{5}{c}{ Drug and rating } & \\
\cline { 2 - 6 } & $\mathrm{A}, 4$ & $\mathrm{~B}, 2$ & $\mathrm{C}, 3$ & $\mathrm{D}, 1$ & $\mathrm{E}, 5$ & Total \\
\hline Satisfactory & 5 & 12 & 6 & 10 & 1 & 34 \\
Unsatisfactory & 9 & 4 & 8 & 2 & 10 & 33 \\
Total & 14 & 16 & 14 & 12 & 11 & \\
\hline
\end{tabular}

Conclusions: There is over-all significance at the 1 per cent level. (1) D is better than $A$ at the 5 per cent level. (2) $D$ is better than $E$ at the 1 per cent level. (3) $B$ is better than $\mathrm{E}$ at the 1 per cent level. 


\section{Drowsiness}

Again it was assumed that less drowsiness was the more desirable state of patients on leaving the operating room. This criterion is essentially the same as No. 1 above but is a clinical evaluation made by the nurses in the recovery room. Patients were classed from 0 (mildly drowsy) to 3 (not rousable for a prolonged period) (Table IX). The results corroborated the findings in No. 1 and showed drugs $B$ and $D$ as superior.

TABLE IX

DRoWsiness (POSTOPERATIVE)

(Clinical observation)

\begin{tabular}{|c|c|c|c|c|c|c|}
\hline & \multicolumn{5}{|c|}{ Drug and rating } & \multirow[b]{2}{*}{ Tota } \\
\hline & A, 4 & $\mathrm{~B}, 2$ & $3, \mathrm{C}$ & $D, 1$ & $\mathrm{E}, 5$ & \\
\hline $\begin{array}{l}\text { Satisfactory } \\
\text { Unsatisfactory }\end{array}$ & $\begin{array}{r}2 \\
12\end{array}$ & $\begin{array}{r}12 \\
4\end{array}$ & $\begin{array}{l}7 \\
7\end{array}$ & $\begin{array}{r}12 \\
0\end{array}$ & $\begin{array}{r}0 \\
11\end{array}$ & $\begin{array}{l}33 \\
34\end{array}$ \\
\hline Total & 14 & 16 & 14 & 12 & 11 & \\
\hline
\end{tabular}

Conclusions: There is over-all significance at well beyond the 1 per cent level. (1) $D$ is better than $C$ at the 2 per cent level. (2) D is better than $A$ and $E$ at the 1 per cent level. (3) $\mathrm{B}$ is better than $\mathrm{A}$ and $\mathrm{E}$ at the 1 per cent level. (4) C is better than $\mathrm{E}$ at the 5 per cent level.

3. Pain and Analgesic Requirements (Pantopon) in the Recovery Room

From the findings in 1 and 2 , above, one might conclude that the ideal postoperative state referred to would merely mean that the patients showing least drowsiness were suffering more. This was investigated by two methods: $(a)$ pain was assessed clinically by the nurses in the recovery room and rated 0 (comfortable) to 3 (complaining bitterly) and $(b)$ the total amount of pantopon administered in the recovery room was noted (none used being considered satisfactory).

There was no significant difference in either $(a)$ or $(b)$ (Table X). Further

TABLE X

Pain and Analgesic Required in Recovery Room

\begin{tabular}{|c|c|c|c|c|c|c|}
\hline & \multicolumn{5}{|c|}{ Drug } & \multirow[b]{2}{*}{ Total } \\
\hline & A & $\mathrm{B}$ & $\mathrm{C}$ & $\mathrm{D}$ & $\mathrm{E}$ & \\
\hline \multicolumn{7}{|c|}{ (a) Pain (Clinically assessed by the nurses) } \\
\hline $\begin{array}{l}\text { Satisfactory rating }-0 \text { and } 1 \\
\text { Unsatisfactory rating }-2 \text { and } 3\end{array}$ & $\begin{array}{l}6 \\
8\end{array}$ & $\begin{array}{l}9 \\
7\end{array}$ & $\begin{array}{l}6 \\
8\end{array}$ & $\begin{array}{l}6 \\
6\end{array}$ & $\begin{array}{l}7 \\
t\end{array}$ & $\begin{array}{l}34 \\
33\end{array}$ \\
\hline Total & 14 & 16 & 14 & 12 & 11 & \\
\hline \multirow{3}{*}{$\begin{array}{l}\text { (b) Pantopon required } \\
\text { Satisfactory none } \\
\text { Unsatisfactory-pantopon gr. } 1 / 6 \\
\text { and } 1 / 3\end{array}$} & & & & & & \\
\hline & 11 & 5 & 7 & 5 & 7 & 35 \\
\hline & 3 & 11 & 7 & 7 & 4 & 32 \\
\hline Total & 14 & 16 & 14 & 12 & 11 & \\
\hline
\end{tabular}


investigation revealed that those patients showing least drowsiness seemed to require less postoperative sedation.

\section{Postoperative Respiratory Depresision}

Evaluation of this function by measurement of "Respiratory minute volume" proved impractical. It was decided to evaluate it by: (a) clinical observation of respiration per minute and necessity for oxygen administration in the recovery room, as recorded by the nurses (Table XI) and (b) noting the amount of Lorfan used immediately after cessation of anaesthesia (none was required in the recovery room) (Table XII).

The difference found is very significant, with drugs $B$ and $D$ producing much less respiratory depression.

TABLE XI

Postoperative Respiratory Depression

\begin{tabular}{lrrrrrrr}
\hline \multicolumn{7}{c}{ Drug and rating } & \\
\cline { 2 - 6 } & $\mathrm{A}, 3$ & $\mathrm{~B}, 1$ & $\mathrm{C}, 4$ & $\mathrm{D}, 2$ & $\mathrm{E}, 5$ & Total \\
\hline Satisfactory & 6 & 13 & 5 & 9 & 1 & 34 \\
Unsatisfactory & 8 & 3 & 9 & 3 & 10 & 33 \\
Total & 14 & 16 & 14 & $1 / 2$ & 11 & \\
\hline
\end{tabular}

Conclusions: There is over-all significance at well beyond the 1 per cent level. (1) $B$ is better than $C$ at the 5 per cent level. (2) $B$ is better than $\mathrm{E}$ at the 1 per cent level. (3) $\mathrm{D}$ is better than $\mathrm{E}$ at the 1 per cent level.

TABLE XII

LORFAN REQUIRED AFTER ANAESTHESIA

\begin{tabular}{lrrrrrr}
\hline & \multicolumn{6}{c}{ Drug and rating } \\
\cline { 2 - 6 } & A, 3 & B, 1 & C, 4 & D, 2 & E, 5 & , Total \\
\hline Satisfactory & 10 & 14 & 7 & 12 & 1 & 44 \\
Unsatisfactory & 4 & 2 & 7 & 0 & 10 & 23 \\
Total & 14 & 16 & 14 & 12 & 11 & \\
\hline
\end{tabular}

Conclusions: There is over-all significance at well beyond the 1 per cent level. (1) D is better than $\mathrm{C}$ at the 2 per cent level. (2) $\mathrm{D}$ is better than $\mathrm{E}$ at the 1 per cent level. (3) $\mathrm{B}$ is bet ter than $\mathrm{E}$ at the 1 per cent level. (4) A is better than $\mathrm{E}$ at the 1 per cent level.

\section{Postoperative Cardiovascular Depression}

This is most difficult to evaluate. We used three criteria:

(a) Clinical observations, in which the appearance of the patient as well as the blood pressure was rated 0 (perfectly well) to 3 (showing some signs of shock) (Table XIIIA). The drugs were not associated with any significant difference by this criterion.

(b) Maximum drop in blood pressure in the recovery room (compared with the patient's usual blood pressure). This ranged all the way from no change to a drop of $75 \mathrm{~mm}$. Hg. A drop of 0 to $20 \mathrm{~mm}$. Hg was termed satisfactory, over $20 \mathrm{~mm}$. $\mathrm{Hg}$ unsatisfactory (Table XIIIB). The drugs were not associated with any significant difference by this criterion. 
(c) Change in blood pressure immediately after termination of anaesthesia (compared with the patient's usual blood pressure). Again there was a wide range, from a rise in blood pressure of $35 \mathrm{~mm}$. $\mathrm{Hg}$ to a drop of $65 \mathrm{~mm}$. $\mathrm{Hg}$. Dividing these values into two approximately equal groups resulted in considering a rise and no change in blood pressure as satisfactory while any drop in blood pressure was considered unsatisfactory (Table XIIIC). Again these drugs were not associated with any significant difference in this criterion.

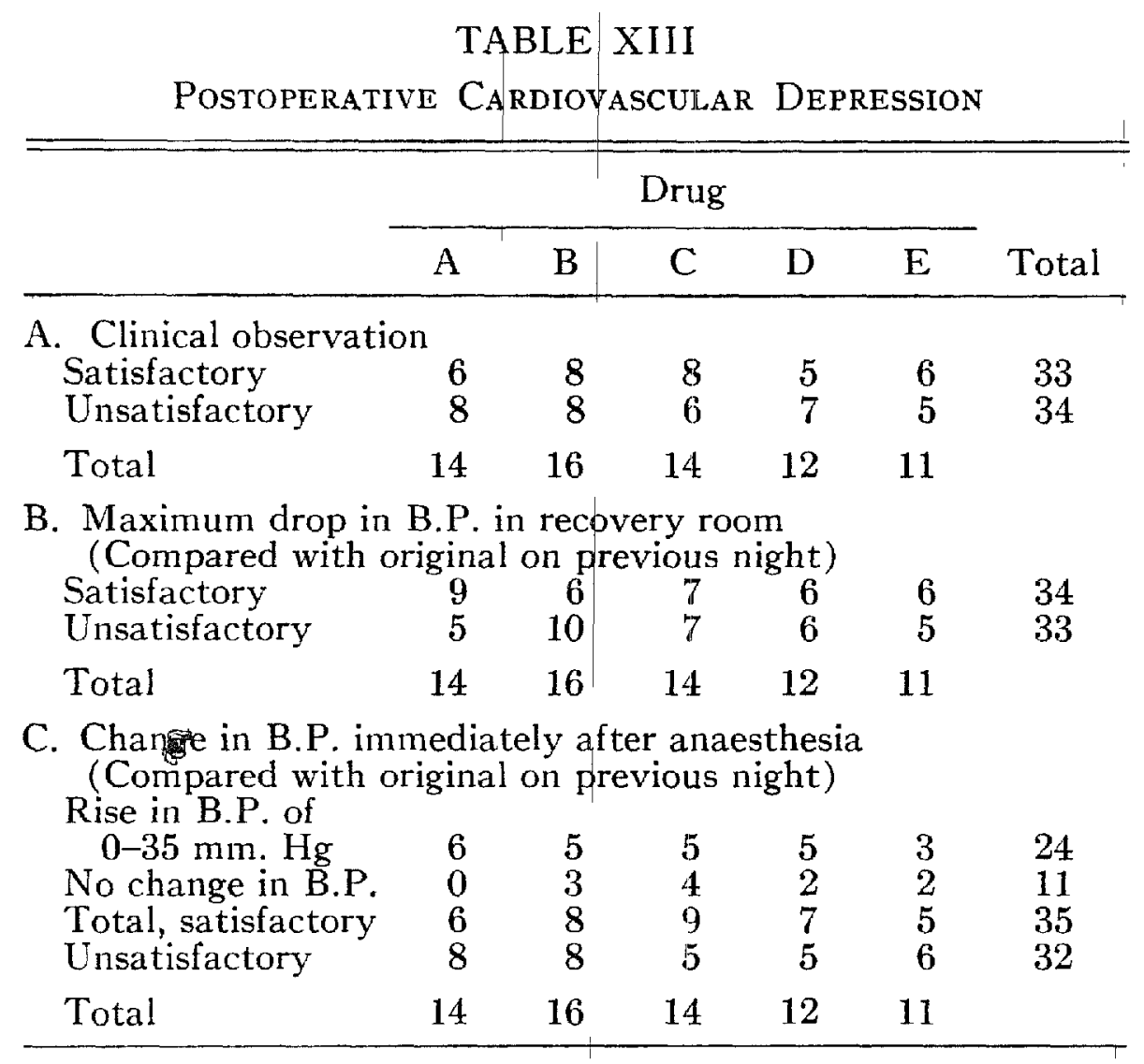

\section{Nausea and Vomiting}

This was evaluated by recording the number of episodes of nausea and vomiting $(a)$ in the operating room immediately following surgery; $(b)$ in the recovery room; $(c)$ during the next 24 hours. These were totalled for each patient, and this number (which ranged from 0 to 11 ) was used for comparison. Only those with a rating of 0 or 1 (that is patients who had only one episode of nausea but no vomiting) were classed as satisfactory (Table XIV). Again there was no significant difference among the drugs used.

TABLE XIV

NaUsea and Vomiting in the Recovery RoOM

\begin{tabular}{|c|c|c|c|c|c|c|}
\hline & \multicolumn{5}{|c|}{ Drug } & \multirow[b]{2}{*}{ Total } \\
\hline & $\mathrm{A}$ & $\mathrm{B}$ & $\mathrm{C}$ & $\mathrm{D}$ & $\mathrm{E}$ & \\
\hline \multirow{2}{*}{$\begin{array}{l}\text { Satisfactory } \\
(0-1) \\
\text { Unsatisfactory } \\
(2 \text { or more })\end{array}$} & 5 & 7 & 9 & 3 & 7 & 31 \\
\hline & 9 & 9 & 5 & 9 & 4 & 36 \\
\hline Total & 14 & 16 & 14 & 12 & 11 & \\
\hline
\end{tabular}




\section{Time in the Recovery Room}

We were surprised at the length of stay and the wide variations. However, there was no significant difference:

TABLE XV

Time in Recovery Room

(Minimum-2 hr. $10 \mathrm{~min}$. Maximum-10 hr.)

\begin{tabular}{lrrrrrrr}
\hline \hline & \multicolumn{6}{c}{ Drug } \\
\cline { 2 - 6 } & $\mathrm{A}$ & $\mathrm{B}$ & $\mathrm{C}$ & $\mathrm{D}$ & $\mathrm{E}$ & Total \\
\hline $\begin{array}{l}\text { Satisfactory } \\
\quad(2.10 \text { to } 4.20 \mathrm{hr} .)\end{array}$ & 8 & 5 & 6 & 8 & 7 & 34 \\
$\quad \begin{array}{l}\text { Unsatisfactory } \\
(4.45 \text { to } 10.00 \mathrm{hr} .)\end{array}$ & 6 & 11 & 8 & 4 & 4 & 33 \\
Total & 14 & 16 & 14 & 12 & 11 & \\
\hline
\end{tabular}

\section{CONCLUSION}

From this small series of tests it would seem that the five drugs are essentially of equal value for the purpose of supplementing surgical analgesia in the anaesthesia techniques described. However, two drugs B and D, seemed to have some advantages over the others in the following respects:

(1) They produced less respiratory depression, both during surgery and during the recovery period.

(2) They left patients in a better postoperative state, i.e. better oriented, more co-operative, and less drowsy or depressed. Table XVI shows the standing of each drug in these respects (drug B is Ciba 20684-BA and drug D is oxymorphan).

\section{TABLE XVI}

Drug Rating

\begin{tabular}{lllllll}
\hline & \multicolumn{5}{c}{ Drug } \\
\cline { 2 - 6 } & A & B & C & D & E \\
\hline During surgery & & & & & \\
$\quad$ Respiratory depression & 3 & 1 & 5 & 2 & 4 \\
Postoperative & & & & & \\
$\quad$ Orientation and co-operation & 4 & 2 & 3 & 1 & 5 \\
$\quad$ Drowsiness & 4 & 2 & 3 & 1 & 5 \\
$\quad$ Respiratory depression & 3 & 1 & $\mathbf{4}$ & 2 & 5 \\
$\quad$ Lorfan requirement & 3 & $\mathbf{1}$ & $\mathbf{4}$ & $\mathbf{2}$ & $\mathbf{5}$ \\
\hline
\end{tabular}

We wish to emphasize that the rigid dosage of drugs used in this series is NOT the recommended dosage for general use. Dosage must be based upon the condition and status of the patient. Further, under normal conditions the initial or pre-operative dose used here is omitted, proper premedication with the drug being given with the atropine one hour before anaesthesia.

Finally, it must be emphasized that the differences we have found between the drugs are based on the potency ratio summarized in Table II. Therefore, a demonstration that these ratios are in error would invalidate our inference that the drugs differ in efficiency. 


\section{SUMMARY}

We have compared five analgesics used to supplement anaesthesia with thiopentone, nitrous oxide, and succinylcholine by means of a rather unorthodox technique involving the use of equipotent dilutions of the drugs in fixed amount at exact intervals.

We believe that we have demonstrated that oxymorphan (Numorphan ${ }^{\circledR}$ ) and Ciba compound 20684-BA have some definite advantages over the other drugs studied.

\section{ACKNOWLEDGMENTS}

The following pharmaceutical firms kindly supplied drugs for testing: Burroughs Wellcome \& Co. (Canada) Ltd., Montreal, P.Q., Ciba Co. Ltd., Montreal, P.Q., Merck Sharp \& Dohme of Canada Ltd., Montreal, P.Q., and Endo Drugs (Canada) Ltd., Montreal, P.Q. The Systolic Monitor was supplied by Burroughs Wellcome Company and the Minute Volume Meter by Ciba Company.

This study was made possible by the kind co-operation and assistance of the nursing staff of the recovery room and of the gynaecologists and their operating room staff. We also wish to acknowledge the assistance of Doctor A. K. Reynolds, Associate Professor of Pharmacology; and Doctor G. Robson of Montreal for their suggestions during the preparation of the manuscript.

\section{RÉstué}

Nous avons comparé cinq produits analgésiques employés pour supplémenter l'anesthésie au pentothal, au protoxide d'azote et au succinylcholine, par une méthode plutôt unorthodox, employant des dilutions équipuissantes de chaques drogues administrés à une dose fixe.

Nous croyons avoir demontré que le Numorphan et la drogue expérimentale, Ciba 20684-BA, sont supérieurs aux autres, produisants moins de dépression respiratoire pendant et après l'opération. Pendant la périod de recouvrement les patients sont moins déprimés et endormis, et ils sont mieux orientés et plus cooperatifs qu'avec les autres trois produits.

\section{REFERENCES}

1. Beecher, Henry K. Measurement of Subjective Responses. New York: Oxford University Press (1959).

2. Gratenstein, J. S.; Smith, G. M.; Sphire, R. D.; Isaacs, J. Pi ; \& Beecher, H. K. Dehydirocodeine, Further Development in Measurement of Analgesic Power and Appraisal of Psychologic Side Effects of Analgesic Agents. New Eng. Med. J. 254: 19 (May, 1956).

3. Keats, A. S. \& Beechfr, H. K. Analgesic Potency and Side Action Liability in Man of Heptozone (Phenadoxone). Win 1161-2, Six Methyl Dihydromorphinone, Metopan (Morphine Derivative) and Pentobarbital Sodium as Further Effort to Refine Methods of Evaluation of Analgesic Drugs. J. Pharmacol. \& Exper. Therap. 105: 109-129 (June, 1952).

4. Wyant, G. M.; Chung, A. C.; \& Cockings, E. C. A Clinical Comparison of Sodium Thiopental (Pentothal ${ }^{\circledR}$ ), Sodium Methitural (Neraval ${ }^{\circledR}$ ), Sodium Buthalitone (Transithal ${ }^{\circledR}$ ), and Sodium .Hexobarbital (Evipal $\left.{ }^{\circledR}\right)$. Canad. Anaesth. Soc. J. 6: 108-118 (1959). 